\title{
One-Year Monitoring of Daily Earthworm Cast Production: Surface Cast Contribution to Soil Fertility in a Subtropical Forest
}

\author{
Xiaoling Wang ${ }^{1}$, Shenglei Fu ${ }^{2}$, Xiaoli Wang ${ }^{3}$, Zhigang $\mathrm{Li}^{1}$, Jianxiong $\mathrm{Li}^{1}{ }^{\text {, }}$ and Weixin Zhang ${ }^{2} \mathbb{D}$ \\ 1 Guangdong Key Laboratory of Animal Conservation and Resource Utilization, Guangdong Public \\ Laboratory of Wild Animal Conservation and Utilization, Institute of Zoology, Guangdong Academy of \\ Sciences, Guangzhou 510260, China; wangxl@giz.gd.cn (X.W.); leegdei@163.com (Z.L.); \\ 2 Key Laboratory of Geospatial Technology for the Middle and Lower Yellow River Regions, Ministry of \\ Education, College of Geography and Environmental Science, Henan University, Kaifeng 475004, China; \\ fs1@henu.edu.cn (S.F.); weixinzhang@139.com (W.Z.) \\ 3 State Key Laboratory of Plateau Ecology and Agriculture, Qinghai Academy of Animal and Veterinary \\ Sciences, Qinghai University, Xining 810016, China; wxl.yu@163.com \\ * Correspondence: 1jx196208@126.com; Tel.: +86-020-84183744
}

Citation: Wang, X.; Fu, S.; Wang, X.; Li, Z.; Li, J.; Zhang, W. One-Year Monitoring of Daily Earthworm Cast Production: Surface Cast Contribution to Soil Fertility in a Subtropical Forest. Forests 2021, 12, 865. https://doi.org/10.3390/ f12070865

Academic Editor: Choonsig Kim

Received: 7 June 2021

Accepted: 29 June 2021

Published: 30 June 2021

Publisher's Note: MDPI stays neutral with regard to jurisdictional claims in published maps and institutional affiliations.

Copyright: (c) 2021 by the authors. Licensee MDPI, Basel, Switzerland. This article is an open access article distributed under the terms and conditions of the Creative Commons Attribution (CC BY) license (https:// creativecommons.org/licenses/by/ $4.0 /)$.
Abstract: The process of earthworm casting plays an important role in soil fertility. The contributions of earthworm casts to soil nutrients dynamics cannot be fully understood unless the temporal changes in earthworm cast production and the related nutrient resource pools are explored in the field. Here, we recorded the daily surface cast production of earthworms and monthly change patterns of carbon $(\mathrm{C})$, nitrogen $(\mathrm{N})$ and phosphorous $(\mathrm{P})$ in casts in a subtropical plantation for one year and compared the nutrient concentrations and microbial community traits (structure and bacterial activity) in casts with those in bulk soils. Our objectives were to characterize the temporal patterns of earthworm cast production and the $\mathrm{C}$ and nutrients in casts and to assess the potential contribution of earthworm casts to soil fertility. The results showed that the annual surface cast production at the study site was 8.3 tons ha ${ }^{-1}$; monthly cast production was $>80 \mathrm{~g} \mathrm{~m}^{-2}$ during April to November and $<30 \mathrm{~g} \mathrm{~m}^{-2}$ during December to March. The annual outputs of total organic C (TOC), total N (TN) and total P (TP) in surface casts were $68.10,4.84$ and $0.38 \mathrm{~g} \mathrm{~m}^{-2}$, respectively; the annual outputs of available $\mathrm{P}$ (AP), $\mathrm{NH}_{4}{ }^{+}-\mathrm{N}$ and $\mathrm{NO}_{3}{ }^{-}-\mathrm{N}$ were $22.4,147.0$ and $61.3 \mathrm{mg} \mathrm{m}^{-2}$, respectively. The concentrations of TOC and TN in casts were higher during warm months, but $\mathrm{NH}_{4}{ }^{+}-\mathrm{N}$ was higher during cold months, while both the concentrations of TP and AP in casts were constant throughout the year. The nutrient concentrations were 1.6-4.3-fold greater, and the microbial biomass $\mathrm{C}$ and $\mathrm{N}$ contents were 7-8-fold greater in earthworm casts than those in bulk soils. However, the bacterial stress index (BSI) was significantly greater in casts than in the bulk soil, which implies that bacteria in casts were under stress. Accordingly, the ratio of fungal to bacterial biomass (F/B) was significantly higher in casts than in the bulk soil. Earthworm casting activity can process forest soil into a "new soil", which forms large amounts of earthworm-induced hotspots of soil fertility. These resource pools in casts, with monthly fluctuated $\mathrm{C}$ and $\mathrm{N}$ and constant $\mathrm{P}$, could be more readily accessed by fungi rather than bacteria. Earthworm casting activity potentially changes both the nutrients available and the interactions of plants and rhizosphere microbiota.

Keywords: nutrient cycling; casting activity; PLFAs; bacterial stress index

\section{Introduction}

Although earthworm casts are considered to be more fertile than bulk soil [1], the contributions of earthworm casting activity to soil fertility have not been fully understood. The positive effects of earthworm casts on vegetation were attributed to high concentrations and availability of soil nutrients, improved physical structure of the soil, enzyme activities 
and an effect of microbial inoculation [2-6]. Earthworm casting processes were considered to be a natural way to maintain soil quality [7].

Many studies have focused on the effects of earthworm casts on the physical structure and nutrient cycling of the soil [8-11]. Mariani et al. [12] inoculated fresh surface casts into artificial soil burrows and found available $\mathrm{N}$ in casts was initially at levels several times higher than that in the bulk soil, while total $\mathrm{C}$ was also significantly higher compared with that in the soil. Higher microbial population densities were observed in casts than in the surrounding mineral soil [13-15]. The casting process resulted in a greater soil microbial biomass C (MBC) or N (MBN) [16,17] and improved nutrient availability [18]. Over longer periods of time, organic matter $(\mathrm{OM})$ within aggregates was protected from further decomposition in the dried and aging casts, as long as casts were not physically disturbed [2,19-21]. Recent research reported that the increase in soil $\mathrm{NH}_{4}{ }^{+}$induced by the earthworm Pontoscolex corethrurus was efficiently utilized by the plants with greater colonization of arbuscular mycorrhizal fungi (AMF) [22], which suggested that nutrients derived from earthworm casts may only be accessible to certain groups of soil biota.

A few studies have been conducted in order to assess the potential contribution of earthworm casts to soil fertility under field conditions. James [9] calculated the surface cast production in a tallgrass prairie and found that the mass of casts produced was 0.36 $7.5 \mathrm{~kg} \mathrm{~m}^{-2} \mathrm{y}^{-1}$, and the turnover time of surface soil was 10-20 years. Organic matter and available $\mathrm{N}$ in the total cast production were estimated at $500-700 \mathrm{~g} \mathrm{~m}^{-2} \mathrm{y}^{-1}$ and $500-550 \mathrm{mg} \mathrm{m}^{-2} \mathrm{y}^{-1}$, respectively. A similar value was estimated in a beech wood forest on limestone soil, with a cast production of $4.23 \mathrm{~kg} \mathrm{ha}^{-1} \mathrm{y}^{-1}$ [23]. A longer term and more detailed change pattern of earthworm cast production in the field and a pattern associated with $C$ and nutrients were not known. Furthermore, the availabilities of $C$ and nutrients in casts to soil microbes were not fully examined, which hampered the mechanistic understanding of the contributions of casts to soil fertility.

Earthworms and their casting activity may play essential roles in sustaining the ecosystem productivity in tropical and subtropical plantations where acid-infertile soils dominate $[12,24,25]$. In this study, earthworm cast production dynamics were monitored by collecting casts daily throughout a whole year in a plantation forest, except for on rainy days. The monthly and annual accumulation of $C$ and nutrients in the casts were calculated. We also compared the $\mathrm{C}$ and nutrient concentrations and the biomass and activity of microbial communities in earthworm casts with those in bulk soils. Our objectives were (1) to characterize the temporal patterns of earthworm cast production and the $C$ and nutrients in casts in the field and (2) to determine both the chemical characteristics and microbial community traits in casts and, thus, assess the potential contribution of earthworm casts to soil fertility.

\section{Materials and Methods}

\subsection{Site Description}

The experiments were performed over a one-year period at Heshan Hilly Land Interdisciplinary Experimental Station $\left(112^{\circ} 50^{\prime} \mathrm{E}, 22^{\circ} 34^{\prime} \mathrm{N}\right)$, Chinese Academy of Sciences, Guangdong Province, China. The area was under the influence of subtropical monsoons, with a distinct wet season (from April to September) and dry season (from October to March). The annual rainfall during the study period (from July 2016 to June 2017) was $1995 \mathrm{~mm}$, and the annual mean temperature was $22.4{ }^{\circ} \mathrm{C}$. This station was located at an altitude of $80 \mathrm{~m}$, and the soil was an Orthic Acrisol [26].

The forest was a mixture of broadleaved tree species dominated by Schima wallichii Choisy and occupied approximately 3.1 ha of land. The forest was about 30 years old when the experiment started in 2016. Seven species of earthworms, including one exotic species (Pontoscolex corethrurus) and six native pheretimoid species, were recorded [27]. Seasonal variation of earthworm biomass was significant at the study site $(p=0.017)$. P. corethrurus was the dominant earthworm species and accounted for $95 \%$ of the earthworm biomass 
during the sampling periods [22]. It usually lived in 0-10 $\mathrm{cm}$ soils, and surface casting was notable at the study site.

\subsection{Experimental Design and Sampling}

Five $1 \times 1 \mathrm{~m}$ quadrats, at least $3 \mathrm{~m}$ away from each other, were randomly set up in the plantation. To compare the chemical and microbial characteristics between the earthworm casts and the bulk soils, all visually observed fresh casts of earthworms on the soil surface were collected from each quadrat on 1 May 2016; on the same date, soil samples $(0-10 \mathrm{~cm}$, $10-20 \mathrm{~cm}$ and $20-30 \mathrm{~cm}$ ) were collected from the adjacent area of each quadrat. Parts of the fresh samples were freeze-dried for the analysis of phospholipid fatty acids (PLFAs), kept in $4{ }^{\circ} \mathrm{C}$ for measurements of microbial biomass $\mathrm{C}$ and $\mathrm{N}$ with the chloroform fumigation extraction method or air-dried for measurements of chemical properties.

Fresh earthworm casts within each quadrat were then collected daily in the morning (at approximately 9 a.m.) from July 2016 to June 2017. Given that cast sampling from subsurface soil layers will greatly disturb both the forest soil profile and the earthworms, in this study, we only focused on the surface casting activity and, thus, made it possible to monitor earthworm casting activity daily in situ across a year. The sampled casts were air-dried and weighed to show the pattern of daily surface cast production and to estimate the monthly and annual production of surface casts.

\subsection{Chemical Properties Analysis}

The $\mathrm{pH}$ and concentrations of total organic $\mathrm{C}$ (TOC), total $\mathrm{N}$ (TN) and total phosphorus (TP) of the surface casts and bulk soils were measured at the beginning of the experiment. The concentrations of TOC, TN, TP, available phosphorus (AP), $\mathrm{NH}_{4}{ }^{+}-\mathrm{N}$ and $\mathrm{NO}_{3}{ }^{-}-\mathrm{N}$ in air-dried earthworm casts were measured monthly.

The water content of the earthworm casts and the bulk soils were measured by ovendrying for $24 \mathrm{~h}$ at $105{ }^{\circ} \mathrm{C}$. The air-dried samples of casts and the bulk soils were sieved through a $2 \mathrm{~mm}$ screen before analysis. TOC was determined by the dichromate oxidation method. TN was estimated by Kjeldahl digestion with UV spectrophotometric analysis [28]. TP was measured using the molybdenum antimony blue colorimetry method [29]. AP was measured using the molybdenum blue method using Bray's extraction solution. The $\mathrm{pH}$ was measured in a 1:2.5 (w/v) water solution using a $\mathrm{pH}$ meter. $\mathrm{NH}_{4}{ }^{+}-\mathrm{N}$ was determined using the indophenol blue colorimetric method, and $\mathrm{NO}_{3}{ }^{-}-\mathrm{N}$ was measured using the cadmium reduction method with a modified Berthelot reaction [29]. The ratios of $C / N$, $\mathrm{C} / \mathrm{P}, \mathrm{N} / \mathrm{P}$, and $\mathrm{C} / \mathrm{N} / \mathrm{P}$ of earthworm casts and bulk soils were calculated. Monthly contents of the TOC, TN, TP, $\mathrm{AP}, \mathrm{NH}_{4}{ }^{+}-\mathrm{N}$ and $\mathrm{NO}_{3}{ }^{-}-\mathrm{N}$ were estimated based on the carbon and nutrient concentrations of earthworm casts and the monthly cast production.

\subsection{Microbial Properties Analysis}

The microbial community characteristics of the earthworm casts and bulk soils were compared at the beginning of the experiment. MBC and MBN concentrations were measured using the chloroform fumigation extraction method [30]. The microbial community structure was analyzed using the PLFA method as described by Bossio and Scow [31]. The amount of individual fatty acid was quantified based on the amount of 19:0 internal standard. Gram-positive $\left(\mathrm{G}^{+}\right)$bacterial biomass was represented by the PLFAs i15:0, a15:0, i16:0, i17:0 and a17:0, and Gram-negative $\left(\mathrm{G}^{-}\right)$bacterial biomass was represented by the PLFAs 16:1 $\omega 7 \mathrm{c}$, cy17:0 and cy19:0. The total bacterial biomass was estimated by the sum

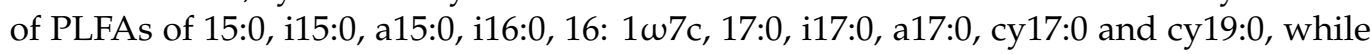
$18: 2 \omega 6,9$ was used as an indicator of fungal biomass [32], and actinomycete biomass was determined by 10Me 16:0, 10Me 17:0 and 10Me 18:0. Total microbial biomass (TPLFA) was estimated from bacterial, fungal and actinomycete biomass. The ratio of fungal PLFAs to bacterial PLFAs was used to estimate the ratio of fungal to bacterial biomass (F/B) in the soils and casts [33]. The ratio of Gram-positive bacterial PLFAs to Gram-negative bacterial 
PLFAs was used to estimate the ratio of Gram-positive to Gram-negative bacterial biomass $\left(\mathrm{G}^{+} / \mathrm{G}^{-}\right)$. The ratio of cy17:0 to $16: 1 \omega 7 \mathrm{c}$ was used as a bacterial stress index (BSI) [34].

\subsection{Statistical Analysis}

One-way ANOVA was performed to examine the temporal dynamics (monthly changes) in earthworm cast production, and the concentrations and contents of total organic $C$ and total and available nutrients in the earthworm casts. One-way ANOVA and LSD test were performed to compare the chemical and microbial traits among the earthworm casts and the 3 layers of bulk soils. All statistics were performed using IBM SPSS Statistics 21 (IBM Inc., New York, NY, USA) and SigmaPlot 12.5 (Systat Software Inc. 2011, San Jose, CA, USA). Redundancy analysis (RDA) was performed in Canoco 4.5 (Wageningen, Netherlands). Differences were considered significant at $p<0.05$.

\section{Results}

\subsection{Earthworm Cast Production}

The production of surface casts of earthworms showed marked variation across the months during the one-year period (Figure $1, p<0.001$ ). Cast production was greatest in the rainy season when temperatures were high and reached a maximum in June. Cast production was low, even negligible, in the dry and relatively cold season. The annual surface cast production was $0.83 \mathrm{~kg} \mathrm{~m}^{-2}$.

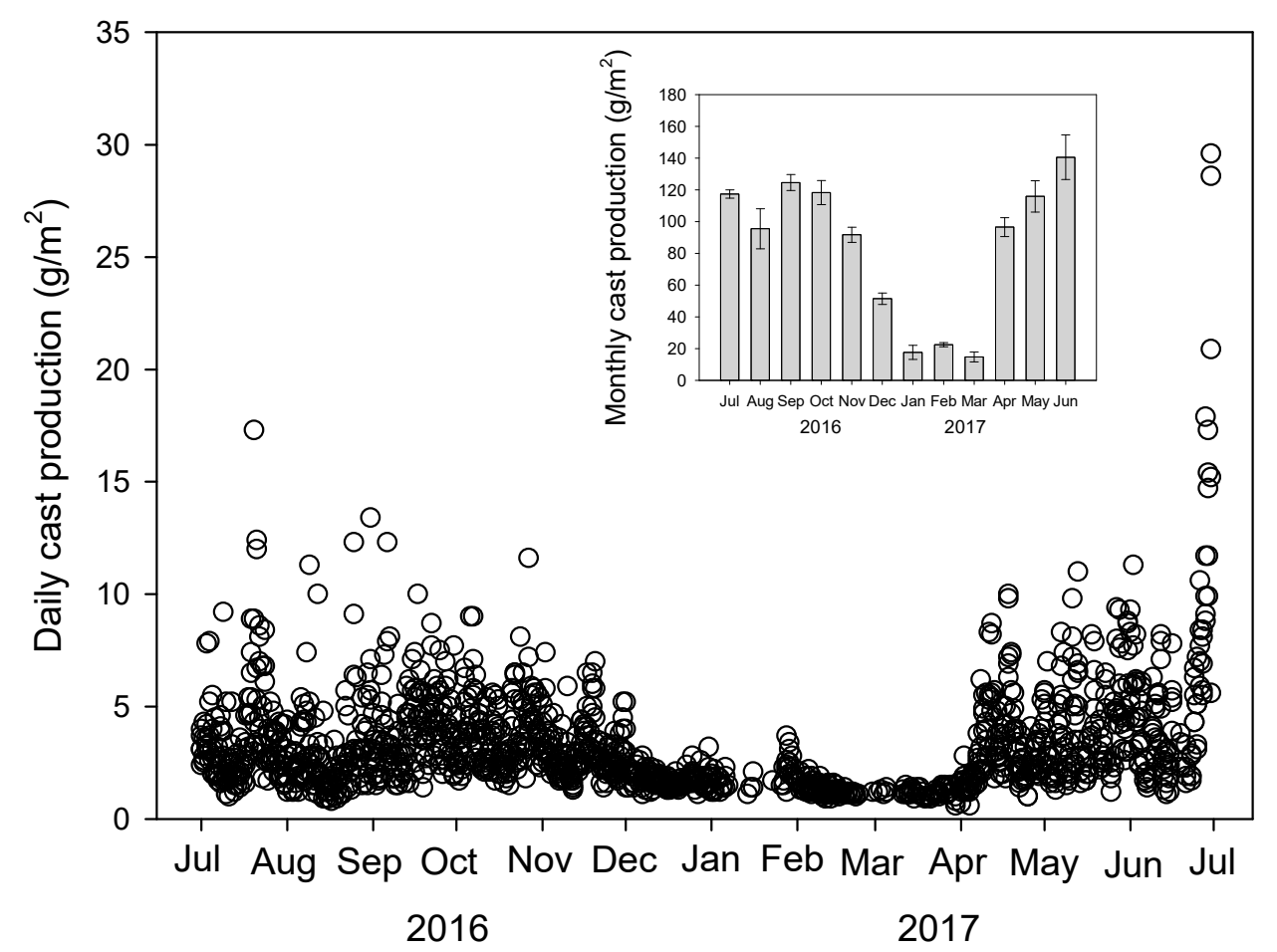

Figure 1. Daily earthworm cast production (dry weight) and monthly earthworm cast production (dry weight, means \pm SE, $n=5$ ) during July 2016 to July 2017 in the studied subtropical plantation.

\subsection{Seasonal Dynamics of Earthworm Cast Nutrients}

The TOC, TN, $\mathrm{NH}_{4}{ }^{+}-\mathrm{N}$ and $\mathrm{NO}_{3}{ }^{-}-\mathrm{N}$ concentrations of earthworm casts varied significantly across the months (Figure $2 \mathrm{~A}, \mathrm{~B}, \mathrm{E}, \mathrm{F}, p<0.001$ ). However, both $\mathrm{TP}$ and $\mathrm{AP}$ were constant throughout the year (Figure $2 \mathrm{C}, \mathrm{D}$ ). Monthly $\mathrm{C}$ and nutrient contents in casts showed similar temporal trends, with higher contents in rainy months and lower contents in the dry and relatively cold months. The estimated annual amounts of TOC, TN and TP in casts were approximately $68.10,4.84$ and $0.38 \mathrm{~g} \mathrm{~m}^{-2}$, respectively. The estimated annual amount of $\mathrm{AP}, \mathrm{NH}_{4}{ }^{+}-\mathrm{N}$ and $\mathrm{NO}_{3}{ }^{-}-\mathrm{N}$ was $22.4,147.0$ and $61.3 \mathrm{mg} \mathrm{m}^{-2}$, respectively. 

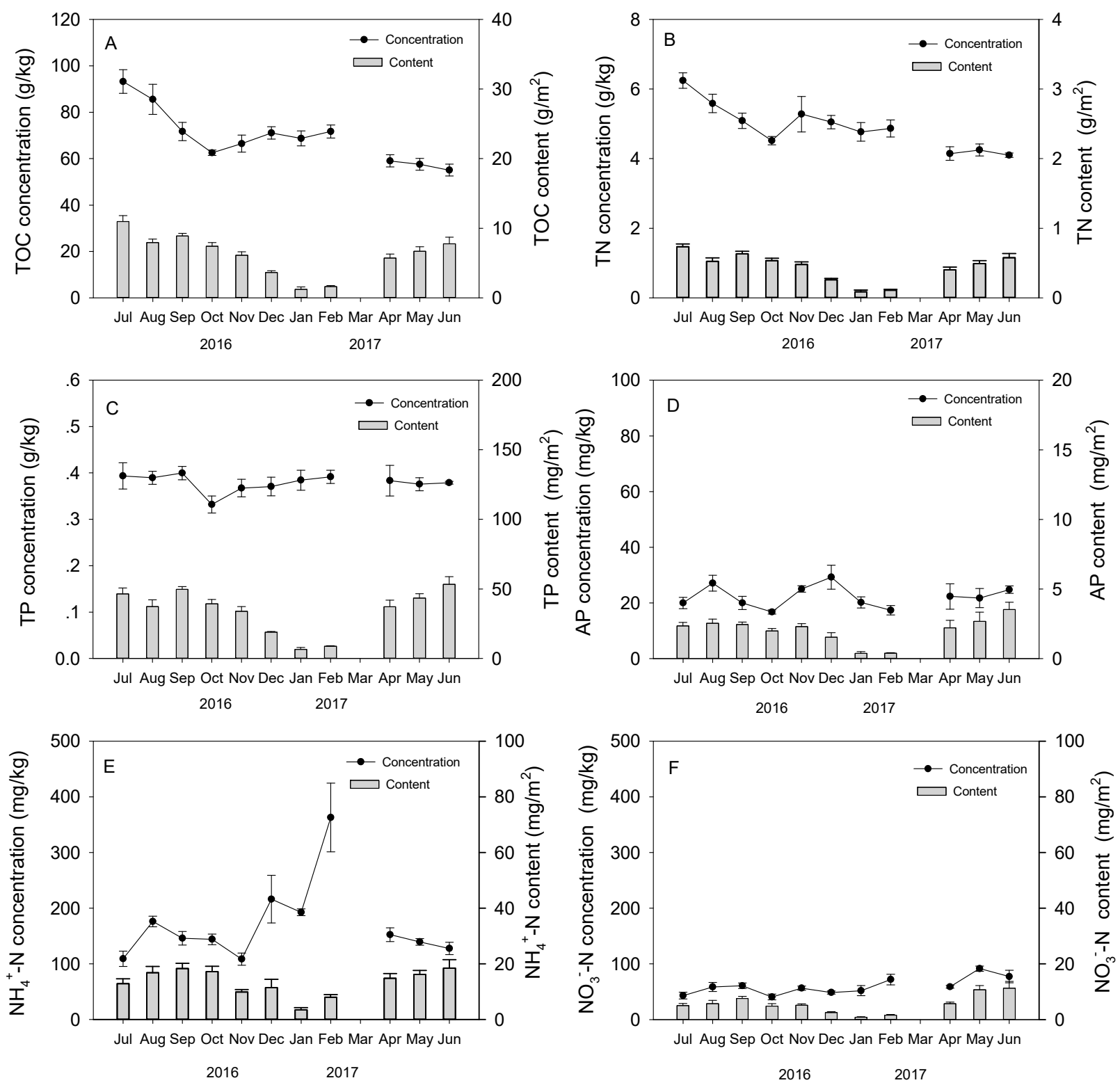

Figure 2. Monthly changes in the concentrations and contents of total organic carbon (TOC) and total and available nutrients in the earthworm surface casts: (A) TOC; (B) total nitrogen (TN); (C) total phosphorus (TP); (D) available phosphorus (AP); (E) ammonium nitrogen $\left(\mathrm{NH}_{4}{ }^{+}-\mathrm{N}\right)$ and $(\mathbf{F})$ nitrate nitrogen $\left(\mathrm{NO}_{3}{ }^{-}-\mathrm{N}\right)$. Data are shown as means $\pm \mathrm{SE}, n=5$. Cast production in March 2017 was too low to be measured.

\subsection{Chemical Properties in Casts and Soil}

The casts contained much more organic $\mathrm{C}, \mathrm{N}$ and $\mathrm{P}$ than the bulk soil did $(p<0.001)$ (Table 1). The $\mathrm{pH}$ value of the casts was significantly higher than that of the topsoil $(0-10 \mathrm{~cm})(p=0.001)$ but not different from that of the deeper layer of soil $(10-20 \mathrm{~cm}$ and $20-$ $30 \mathrm{~cm})$. In addition, the casts had higher $\mathrm{C} / \mathrm{N}, \mathrm{C} / \mathrm{P}$ and $\mathrm{N} / \mathrm{P}$ than bulk soils did $(p<0.001)$ (Table 1). The mean ratio of $\mathrm{C} / \mathrm{N} / \mathrm{P}$ in the earthworm casts was $216 / 12 / 1$, which was considerably different from those in the three soil layers (Table 1 ). 
Table 1. Chemical properties of bulk soils and surface earthworm casts (means $\pm \mathrm{SE}, n=5$ ), including $\mathrm{pH}$, total organic carbon (TOC), total nitrogen (TN) and total phosphorus (TP). Samples were collected in May 2016. Different letters represent significant differences between the three layers of soil and casts (LSD test, $P<0.05)$.

\begin{tabular}{ccccc}
\hline & \multicolumn{3}{c}{ Soil Layer } & Cast \\
\cline { 2 - 4 } & $\mathbf{0 - 1 0 ~} \mathbf{~ c m}$ & $\mathbf{1 0 - 2 0} \mathbf{~ c m}$ & $\mathbf{2 0 - 3 0 ~} \mathbf{~ m}$ & \\
\hline $\mathbf{p H}$ & $4.01 \pm 0.05^{\mathrm{b}}$ & $4.14 \pm 0.03^{\mathrm{a}}$ & $4.21 \pm 0.03^{\mathrm{a}}$ & $4.19 \pm 0.11^{\mathrm{a}}$ \\
$\mathrm{TOC}(\mathrm{g} / \mathrm{kg})$ & $20.8 \pm 1.03^{\mathrm{b}}$ & $8.90 \pm 0.38^{\mathrm{c}}$ & $7.57 \pm 0.8^{\mathrm{c}}$ & $89.5 \pm 6.61^{\mathrm{a}}$ \\
$\mathrm{TN}(\mathrm{g} / \mathbf{k g})$ & $1.71 \pm 0.14^{\mathrm{b}}$ & $0.84 \pm 0.12^{\mathrm{c}}$ & $0.71 \pm 0.10^{\mathrm{c}}$ & $5.08 \pm 0.90^{\mathrm{a}}$ \\
$\mathrm{TP}(\mathrm{g} / \mathrm{kg})$ & $0.26 \pm 0.02^{\mathrm{b}}$ & $0.21 \pm 0.02^{\mathrm{c}}$ & $0.22 \pm 0.02^{\mathrm{c}}$ & $0.41 \pm 0.03^{\mathrm{a}}$ \\
$\mathrm{C} / \mathrm{N}$ & $12.2 \pm 0.5^{\mathrm{b}}$ & $10.8 \pm 0.7^{\mathrm{b}}$ & $10.7 \pm 0.8^{\mathrm{b}}$ & $17.8 \pm 0.9^{\mathrm{a}}$ \\
$\mathrm{C} / \mathrm{P}$ & $82.0 \pm 5.2^{\mathrm{b}}$ & $43.0 \pm 3.1^{\mathrm{c}}$ & $35.8 \pm 4.9^{\mathrm{c}}$ & $216.0 \pm 10.2^{\mathrm{a}}$ \\
$\mathrm{N} / \mathrm{P}$ & $6.7 \pm 0.2^{\mathrm{b}}$ & $4.0 \pm 0.2^{\mathrm{c}}$ & $3.3 \pm 0.3^{\mathrm{c}}$ & $12.2 \pm 0.6^{\mathrm{a}}$ \\
$\mathrm{C} / \mathrm{N} / \mathrm{P}$ & $82 / 7 / 1$ & $43 / 4 / 1$ & $36 / 3 / 1$ & $216 / 12 / 1$ \\
\hline
\end{tabular}

\subsection{Microbial Community Characteristics in Cast and Soil}

MBC and MBN concentrations in casts were $1785.4 \pm 277.0$ and $365.0 \pm 75.3 \mathrm{mg} \mathrm{kg}^{-1}$, respectively, and were 7.2- and 8.2-fold greater, respectively, than that of the surface bulk soils $(p<0.001)$. There was no significant difference in $\mathrm{MBC} / \mathrm{MBN}$ ratio between the earthworm casts and bulk soil (Table 2).

Table 2. Concentrations of microbial biomass carbon (MBC) and nitrogen (MBN) in bulk mineral soils and surface earthworm casts (means \pm SE, $n=5$ ). Samples were collected in May 2016. Different letters represent significant differences among soil layers and casts (LSD test, $P<0.05$ ).

\begin{tabular}{ccccc}
\hline & \multicolumn{3}{c}{ Soil Layer } & \multirow{2}{*}{ Cast } \\
\cline { 2 - 4 } & $\mathbf{0 - 1 0} \mathbf{~ c m}$ & $\mathbf{1 0 - 2 0} \mathbf{~ c m}$ & $\mathbf{2 0 - 3 0 ~} \mathbf{~ m ~}$ & \\
\hline MBC (mg/kg) & $247.6 \pm 30.3^{\mathrm{b}}$ & $114.0 \pm 20.3^{\mathrm{c}}$ & $118.3 \pm 52.3^{\mathrm{c}}$ & $1785.4 \pm 277.0^{\mathrm{a}}$ \\
$\mathrm{MBN}(\mathrm{mg} / \mathrm{kg})$ & $44.3 \pm 7.3^{\mathrm{b}}$ & $17.1 \pm 6.7^{\mathrm{c}}$ & $22.7^{\mathrm{a}} \pm 8.1^{\mathrm{c}}$ & $365.0 \pm 75.3^{\mathrm{a}}$ \\
$\mathrm{MBC} / \mathrm{MBN}$ & $5.6 \pm 0.2^{\mathrm{a}}$ & $8.4 \pm 2.6^{\mathrm{a}}$ & $5.6 \pm 1.1^{\mathrm{a}}$ & $5.1 \pm 0.7^{\mathrm{a}}$ \\
\hline
\end{tabular}

Microbial community characteristics in casts significantly differed from those in the soil ( $p=0.001$ ) (Figure 3A-I). The total microbial PLFAs of casts were $48.4 \mathrm{nmol} \cdot \mathrm{g}^{-1} \mathrm{dry}$ soil, which was 7.8 times that of the soil. Similarly, greater biomasses of bacterial, fungal and actinomycete PLFAs were found in casts compared with that of soil. Higher F/B, $\mathrm{G}^{+}$ and $\mathrm{G}^{-}$bacterial PLFA biomass and BSI were also found in earthworm casts. $\mathrm{G}^{+}$bacteria dominated the microbial communities in both the soils and casts, but the $\mathrm{G}^{+} / \mathrm{G}^{-}$was lower in casts than in the soil $(p=0.001)$.

The RDA analysis showed that soil chemical properties explained approximately 98\% of the total variation in PLFA signatures (Figure 4). TN, TP, C/N, N/P and pH were significantly and positively correlated with the variation in microbial community structure $(p<0.05)$. TN had a strong effect on microbial community composition and explained $95 \%$ of the total variation $(p=0.002)$. The analysis of PLFA-based microbial composition showed that there was an obvious difference in microbial community structure between the casts and the bulk soils (Figure 4). 

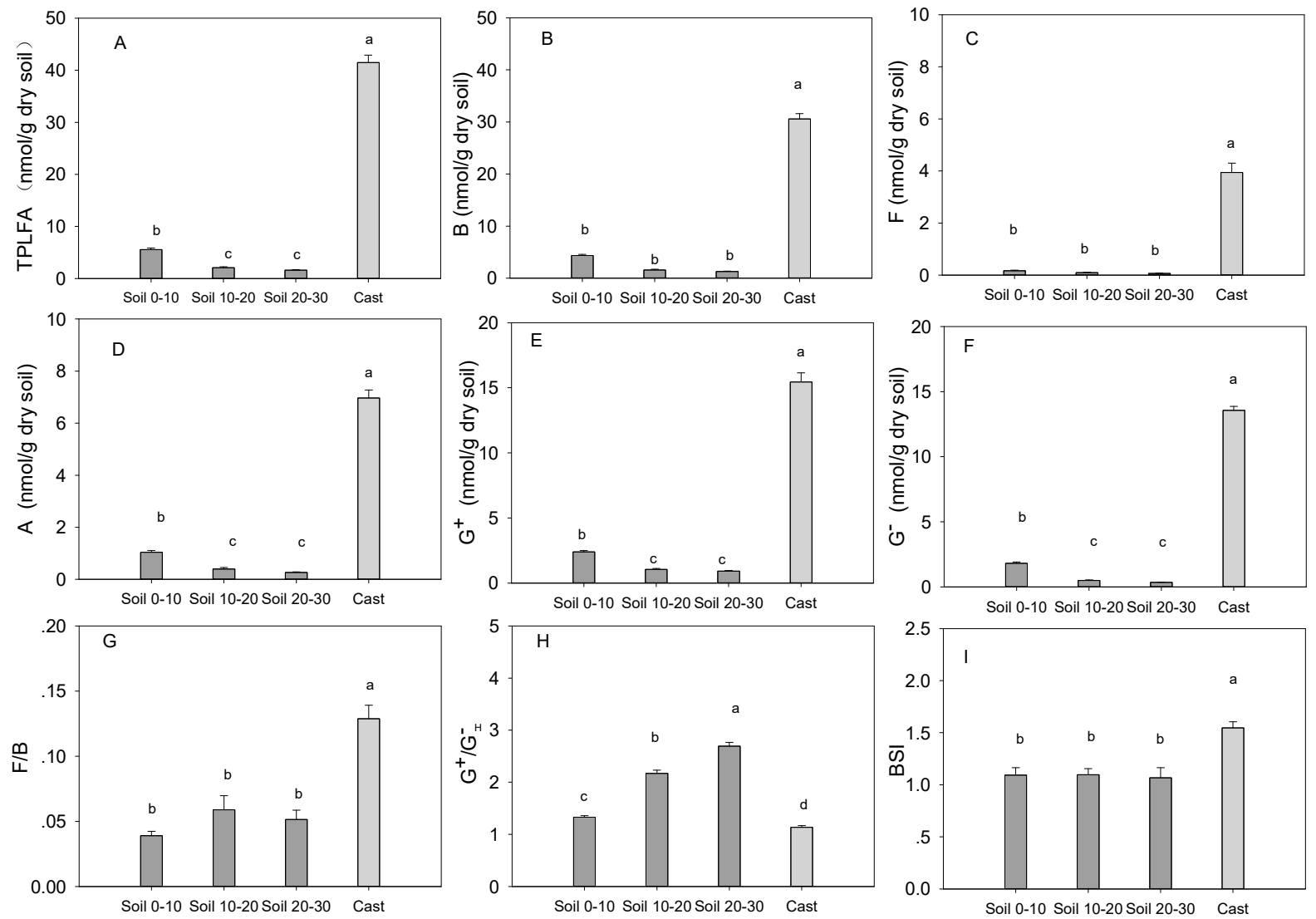

Figure 3. The microbial biomass and community structure in surface earthworm casts and bulk soils. (A) TPLFA, total phospholipid fatty acids which represented total microbial biomass; (B) B, bacterial biomass; (C) F, fungal biomass; (D) A, actinomycete biomass; (E) $\mathrm{G}^{+}$, Gram-positive bacterial biomass; (F) $\mathrm{G}^{-}$, Gram-negative bacterial biomass; (G) F/B; (H) $\mathrm{G}^{+} / \mathrm{G}^{-}$; (I) BSI, bacterial stress index. Samples were collected in May 2016. Data are shown as means $\pm \mathrm{SE}, n=5$. Bars with different letters differed significantly.

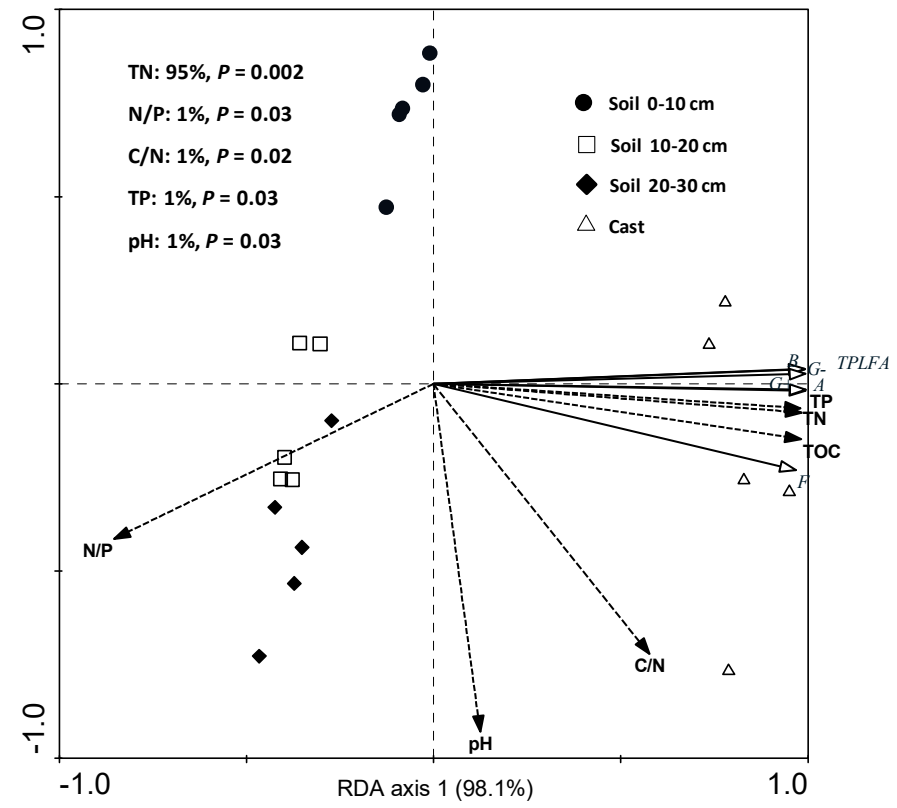

Figure 4. Redundancy analysis of microbial community structure (indicated as phospholipid fatty acids profile) and chemical properties of surface casts and bulk soils. TPLFA, total PLFA; F, fungi; B, bacteria; A, actinomycete; $\mathrm{G}^{+}$, Gram-positive bacteria; $\mathrm{G}^{-}$, Gram-negative bacteria; TOC, total organic carbon; TN, total nitrogen; TP, total phosphorus. 


\section{Discussion}

Surface casting was strong at the study site, although it was dominated by the endogeic earthworm species P. Corethrurus. As expected, large amounts of $\mathrm{C}, \mathrm{N}$ and $\mathrm{P}$ were found to accumulate in earthworm casts. The concentrations of TOC, TN and TP were 4.3, 3.0 and 1.6 times greater in earthworm casts than those in the soils, respectively. Accordingly, some proportions of available nutrients could be released from the casts as stated in the literature $[4,7,8,10,35]$. Earthworms have been reported to concentrate available nutrients in hotpots; for instance, in a tallgrass prairie, the available $\mathrm{N}$ in earthworm casts has been estimated as 500-550 $\mathrm{mg} \mathrm{m}^{-2} \mathrm{y}^{-1}$ [9], which was much higher than in our study $\left(147 \mathrm{mg} \mathrm{m}^{-2} \mathrm{y}^{-1}\right)$. This may depend on the earthworm density, species and litter quality.

The change pattern of monthly cast production was closely related with the temperature and moisture changes. The cast production was greater in the rainy and hightemperature season but was lower in the dry and cold season. This may also be related to earthworm biomass. Significant seasonal variation of earthworm biomass was found at the same study site, which was related to the humidity and soil moisture [27]. Although the seasonal trend of earthworm biomass was not completely consistent with that of the cast production in the current study, there should be an interesting and complex relationship among earthworm biomass, amount of castings and environmental factors, which needs further study.

The nutrient concentrations of earthworm casts significantly varied across months. We noted that the concentrations of both TOC and TN in casts were higher during the warmest periods (July and August), but $\mathrm{NH}_{4}{ }^{+}-\mathrm{N}$ was significantly increased during the coldest periods (December to February). These results indicated that the mineralization intensity in casts was stronger in colder periods. In contrast, both the concentrations of TP and AP in casts were constant throughout the year. In other words, earthworm casts may supply varied amounts of mineral $\mathrm{N}$ but a rather constant amount of $\mathrm{P}$ to soil microbes and plants during the whole year.

The larger microbial community biomass in casts may reflect the rich amount of $\mathrm{C}$ and nutrients during the formation process of casts. Both the chloroform fumigation approach and PLFA analysis showed that the microbial biomass in casts was significantly higher than that in bulk soils. In addition, there was a 1.7- and 2.8-fold increase in the proportion of MBC to TOC and MBN to TN in casts, respectively, compared to that in bulk soils, suggesting more $\mathrm{C}$ and $\mathrm{N}$ were immobilized in the microbial biomass in earthworm casts. These $\mathrm{C}$ and $\mathrm{N}$ pools in microbial biomass could have potentially positive effects on nutrient availability to plants when proper conditions are met [17].

In addition, the observed biomass increases in all the major groups of microbes in casts suggested that pool sizes of both the labile and less labile organic matter were increased during gut passage. The observed lower ratio of $\mathrm{G}^{+}$to $\mathrm{G}^{-}$bacteria in the cast compared to that in the bulk soils suggested that $\mathrm{G}^{-}$bacteria was more stimulated than the $\mathrm{G}^{+}$bacteria during the cast formation. However, it was notable that despite the highly increased biomass of $\mathrm{G}^{-}$bacteria in casts, the observed higher value of BSI in the cast indicated that $\mathrm{G}^{-}$bacteria growth was restricted, probably due to the relatively limited resource accessibility. These results contradicted previous reports in which microbial activity in casts compared to that in soils was found to be increased [36] or unchanged [37]. These discrepancies may be due to the different approaches of measuring microbial activity. The fluorescein diacetate hydrolysis, which Aira et al. [36] used to indicate microbial activity, was an indirect approach based on enzyme activity measurement, whereas the PLFA-based ratio of cy17:0/precursor would directly reflect the metabolism activity of microbes. In fact, the $C$ and nutrients in earthworm casts may tend to be protected in casts $[10,20,38,39]$. The extremely high ratio of $\mathrm{C} / \mathrm{N} / \mathrm{P}(216 / 12 / 1)$, which indicated a relatively limited nutrient availability and reduced organic matter mineralization in the cast $[40,41]$, may explain the stress that the $\mathrm{G}^{-}$bacteria encountered. Earthworm casts are reported to be enriched in polysaccharides and lignin, which serve as cementing agents [42], suggesting an enhanced stabilization of $\mathrm{C}$ and $\mathrm{N}$ inside casts due to their physical protection. The higher $\mathrm{F} / \mathrm{B}$ ratio 
in the cast may also reflect the limited available nutrients in the cast $[41,43]$. Fungi was thought to have a higher efficiency of substrate $C$ use compared with bacteria [44-46]. The increased F/B ratio suggested that fungi played more important roles in the biochemical processes, likely due to its relatively high adaptability to the substantially greater ratios of $\mathrm{C} / \mathrm{N} / \mathrm{P}$ in casts. The increased $\mathrm{F} / \mathrm{B}$ ratio also suggested a slower flow of energy and a higher stability through the soil food webs [47]. This finding is complementary to the observation of the AMF-enhanced utilization of earthworm-induced soil $\mathrm{NH}_{4}{ }^{+}-\mathrm{N}$ by plants [22].

\section{Conclusions}

Earthworm casting activity can process forest soil into a "new soil". The "new soil" is formed of large amounts of earthworm-induced hotspots of soil fertility. These resource pools in casts, containing constant available $\mathrm{P}$ across the year but a higher proportion of mineral $\mathrm{N}$ in colder periods, could be more readily accessed by fungi rather than bacteria. Earthworm casting activity provides a continuous nutrient supply for the plants and potentially enhances the competitive advantages of plant-AMF association over soil bacteria. Although the current study was a case study from one plantation site, these findings add new dimensions for understanding the characteristics of earthworm casts. Given that exploring soil fauna-regulated ecological processes at different spatial and temporal scales is one of the cutting-edge aspects of soil ecology [48], further studies across different types of forest are needed to consolidate the findings.

Author Contributions: Data curation, X.W. (Xiaoling Wang), Z.L. and X.W. (Xiaoli Wang); Formal analysis, X.W. (Xiaoling Wang); Funding acquisition, J.L. and S.F.; Investigation, X.W. (Xiaoling Wang), Z.L. and X.W. (Xiaoli Wang); Project administration, S.F. and W.Z.; Supervision, S.F. and J.L.; Writingoriginal draft, X.W. (Xiaoling Wang); Writing—review \& editing, S.F. and W.Z. All authors have read and agreed to the published version of the manuscript.

Funding: This study was financially supported by GDAS' Project of Science and Technology Development (2019GDASYL-0103060), the National Natural Science Foundation of China (41501268, 31700454 and 41877054), the Youth Innovation Promotion Association of CAS (2015303), the Guangdong Provincial Science and Technology Program (2018B030324001), the Science \& Technology Planning Project of Guangdong Province (2016A020228008, 2019B030316018) and GDAS Special Project of Science and Technology Development (2018GDASCX-0107).

Data Availability Statement: The datasets used and/or analysed during the current study available from the corresponding author on reasonable request.

Acknowledgments: This study was conducted at Heshan Hilly Land Interdisciplinary Experimental Station, Chinese Academy of Sciences. The authors wish to thank Xingquan Rao and Xinxing He for their technical support and help with data analysis, and their advice on the manuscript.

Conflicts of Interest: The authors declare no conflict of interest.

\section{References}

1. Van Groenigen, J.W.; Van Groenigen, K.J.; Koopmans, G.F.; Stokkermans, L.; Vos, H.M.J.; Lubbers, I.M. How fertile are earthworm casts? A meta-analysis. Geoderma 2018, 338, 525-535. [CrossRef]

2. Lavelle, P.; Martin, A. Small-scale and large-scale effects of endogeic earthworms on soil organic matter dynamics in soils of the humid tropics. Soil. Biol. Biochem. 1992, 24, 1491-1498. [CrossRef]

3. Edwards, C.A. Historical overview of vermicomposting. Biocycle 1995, 36, 56-58.

4. Chaoui, H.I.; Zibilske, L.M.; Ohno, T. Effects of earthworm casts and compost on soil microbial activity and plant nutrient availability. Soil. Biol. Biochem. 2003, 35, 295-302. [CrossRef]

5. García-Palacios, P.; Maestre, F.T.; Bradford, M.A.; Reynolds, J.F. Earthworms modify plant biomass and nitrogen capture under conditions of soil nutrient heterogeneity and elevated atmospheric CO2 concentrations. Soil. Biol. Biochem. 2014, 78, 182-188. [CrossRef]

6. Lv, M.; Li, J.; Zhang, W.; Zhou, B.; Zhang, C. Microbial activity was greater in soils added with herb residue vermicompost than chemical fertilizer. Soil. Ecol. Lett. 2020, 2, 209-219. [CrossRef]

7. Saha, S.; Dutta, D.; Ray, D.P.; Karmakar, R. Vermicompost and Soil Quality. In Farming for Food and Water Security; Lichtfouse, E., Ed.; Springer: Berlin/Heidelberg, Germany, 2012. 
8. Barley, K.P.; Jennings, A.C. Earthworms and soil fertility. III. The influence of earthworms on the availability of nitrogen. Aust. J. Agric. Res. 1959, 10, 364-370. [CrossRef]

9. James, S.W. Soil, nitrogen, phosphorus, and organic matter processing by earthworms in tallgrass prairie. Ecology 1991, 72, 2101-2109. [CrossRef]

10. Barois, I.; Villemin, G.; Lavelle, P.; Toutain, F. Transformation of the soil structure through Pontoscolex corethrurus (Oligochaeta) intestinal tract. Geoderma 1993, 56, 57-66. [CrossRef]

11. Kharin, S.A.; Kurakov, A.V. Transformation of nitrogen compounds and dynamics of microbial biomass in fresh casts of Aporrectodea caliginosa. Eurasian. Soil Sci. 2009, 42, 75-81. [CrossRef]

12. Mariani, L.; Juan, J.; Jiménez Asakawa, N.; Thomas, R.J.; Decaëns, T. What happens to earthworm casts in the soil? A field study of carbon and nitrogen dynamics in Neotropical savannahs. Soil. Biol. Biochem. 2007, 39, 757-767. [CrossRef]

13. Scheu, S. Microbial activity and nutrient dynamics in earthworm casts (Lumbricidae). Biol. Fert. Soils 1987, 5, 230-234. [CrossRef]

14. Pashanasi, B.; Melendez, G.; Szott, L.; Lavelle, P. Effect of inoculation with the endogeic earthworm Pontoscolex corethrurus (Glossoscolecidae) on $\mathrm{N}$ availability, soil microbial biomass and the growth of three tropical fruit tree seedlings in a pot experiment. Soil. Biol. Biochem. 1992, 24, 1655-1659. [CrossRef]

15. Nechitaylo, T.Y.; Yakimov, M.; Godinho, M.; Timmis, K.N.; Belogolova, E.; Byzov, B.A.; Kurakov, A.V.; Jones, D.L.; Golyshin, P. Effect of the Earthworms Lumbricus terrestris and Aporrectodea caliginosa on Bacterial Diversity in Soil. Microb. Ecol. 2009, 59, 574-587. [CrossRef]

16. Araujo, Y.; Luizão, F.; Barros, E. Effect of earthworm addition on soil nitrogen availability, microbial biomass and litter decomposition in mesocosms. Biol. Fert. Soils 2004, 39, 146-152. [CrossRef]

17. Groffman, P.M.; Bohlen, P.J.; Fahey, F.T.J. Exotic earthworm invasion and microbial biomass in temperate forest soils. Ecosystems 2004, 7, 45-54. [CrossRef]

18. Wan, J.H.C.; Wong, M.H. Effects of earthworm activity and p-solubilizing bacteria on P availability in soil. J. Plant Nutr. Soil Sci. 2004, 167, 209-213. [CrossRef]

19. Lavelle, P.; Pashanasi, B.; Charpentier, F.; Gilot, C.; Rossi, J.P.; Derouard, L.; Jean André, J.; Ponge, J.F.; Bernier, N. Large-scale effects of earthworms on soil organic matter and nutrient dynamics. In Earthworm Ecology; Edwards, C.A., Ed.; CRC Press: Los Angeles, CA, USA, 1998; pp. 103-122.

20. Decaëns, T.; Mariani, L.; Betancourt, N.; Jiménez, J.J. Seed dispersion by surface casting activities of earthworms in Colombian grasslands. Acta Oecol. 2003, 24, 175-185. [CrossRef]

21. Bossuyt, H.; Six, J.; Hendrix, P.F. Protection of soil carbon by microaggregates within earthworm casts. Soil Biol. Biochem. 2005, 37, 251-258. [CrossRef]

22. He, X.; Chen, Y.; Liu, S.; Gunina, A.; Wang, X.; Chen, W.; Shao, Y.; Shi, L.; Yao, Q.; Li, J.; et al. Cooperation of earthworm and arbuscular mycorrhizae enhanced plant $\mathrm{N}$ uptake by balancing absorption and supply of ammonia. Soil Biol. Biochem. 2018, 116, 351-359. [CrossRef]

23. Scheu, S. The role of substrate feeding earthworms (Lumbricidae) for bioturbation in a beechwood soil. Oecologia 1987, 72,192 . [CrossRef]

24. Henrot, J.; Brussaard, L. Abundance, casting activity, and cast quality of earthworms in an acid ultisol under alley-cropping in the humid tropics. Appl. Soil Ecol. 1997, 6, 169-179. [CrossRef]

25. Hong, H.N.; Rumpel, C.; Tureaux, T.H.D.; Bardoux, G.; Billou, D.; Duc, T.T.; Jouquet, P. How do earthworms influence organic matter quantity and quality in tropical soils? Soil Biol. Biochem. 2011, 43, 223-230. [CrossRef]

26. FAO. World reference base for soil resources 2006. In World Soil Resources Reports No. 103; FAO, UN: Rome, Italy, 2006.

27. Zhang, W.X.; Li, J.X.; Guo, M.F.; Liao, C.H. Seasonal variation of earthworm community structure as correlated with environmental factors in three plantation of Heshan, Guangdong, China. Acta Ecol. Sinica 2005, 25, 1362-1370.

28. Liu, G. Analysis of Soil Physical and Chemical Properties and Description of Soil Profiles; China Standard: Beijing, China, 1996.

29. Fang, Y.T.; Gundersen, P.; Mo, J.M.; Zhu, W.X. Input and output of dissolved organic and inorganic nitrogen in subtropical forests of South China under high air pollution. Biogeosciences 2008, 5, 339-352. [CrossRef]

30. Vance, E.D.; Brookes, P.C.; Jenkinson, D.S. An extraction method for measuring soil microbial biomass C. Soil Biol. Biochem. 1987, 19, 703-707. [CrossRef]

31. Bossio, D.A.; Scow, K.M. Impacts of carbon and flooding on soil microbial communities: Phospholipid fatty acid profiles and substrate utilization patterns. Microb. Ecol. 1998, 35, 265-278. [CrossRef]

32. Frostegård, ̊.; Bååth, E. The use of phospholipid fatty acid analysis to estimate bacterial and fungal biomass in soil. Biol. Fert. Soils 1996, 22, 59-65. [CrossRef]

33. Bååth, E.; Anderson, T.H. Comparison of soil fungal/bacterial ratios in a pH gradient using physiological and PLFA-based techniques. Soil Biol. Biochem. 2003, 35, 955-963. [CrossRef]

34. Wu, J.P.; Liu, Z.F.; Sun, Y.X.; Zhou, L.X.; Lin, Y.B.; Fu, S.L. Introduced Eucalyptus urophylla plantations change the composition of the soil microbial community in subtropical china. Land Degrad. Dev. 2014, 24, 400-406. [CrossRef]

35. Tiwari, S.C.; Tiwari, B.K.; Mishra, R.R. Microbial populations, enzyme activities and nitrogen-phosphorus-potassium enrichment in earthworm casts and in the surrounding soil of a pineapple plantation. Biol. Fert. Soils 1989, 8, 178-182. [CrossRef]

36. Aira, M.; Lazcano, C.; Gómez-Brandón, M.; Domínguez, J. Ageing effects of casts of Aporrectodea caliginosa on soil microbial community structure and activity. Appl. Soil Ecol. 2010, 46, 143-146. [CrossRef] 
37. Aira, M.; Domínguez, J. Changes in nutrient pools, microbial biomass and microbial activity in soils after transit through the gut of three endogeic earthworm species of the genus Postandrilus Qui and Bouché, 1998. J. Soil Sediment 2014, 14, 1335-1340. [CrossRef]

38. Shaw, C.; Pawluk, S. Faecal microbiology of Octolasion tyrtaeum, Aporrectodea turgida and Lumbricus terrestris and its relation to the carbon budgets of three artificial soils. Pedobiologia 1986, 29, 377-389.

39. Zhang, W.X.; Hendrix, P.F.; Damem, L.E.; Burke, R.A.; Wu, J.P.; Neher, D.A.; Li, J.X.; Shao, Y.H.; Fu, S.L. Earthworms facilitate carbon sequestration through unequal amplification of carbon stabilization compared with mineralization. Nat. Commun. 2013, 4, 2576. [CrossRef]

40. Tisdale, S.L.; Nelson, W.L. Soil fertility and fertilizers. Q. Rev. Biol. 1966, 101, 193. [CrossRef]

41. Högberg, M.N.; Chen, Y.; Högberg, P. Gross nitrogen mineralisation and fungi-to-bacteria ratios are negatively correlated in boreal forests. Biol. Fert. Soils 2007, 44, 363-366. [CrossRef]

42. Alekseeva, T.; Besse, P.; Françoise, B.; Delort, A.M.; Tixier, C. Effect of earthworm activity (Aporrectodea giardi) on atrazine adsorption and biodegradation. Eur. J. Soil Sci. 2006, 57, 295-307. [CrossRef]

43. Blagodatskaya, E.V.; Anderson, T.H. Interactive effects of $\mathrm{pH}$ and substrate quality on the fungal-to-bacterial ratio and $\mathrm{qCO}_{2}$ of microbial communities in forest soils. Soil Biol. Biochem. 1998, 30, 1269-1274. [CrossRef]

44. Sakamoto, K.; Oba, Y. Effect of fungal to bacterial biomass ratio on the relationship between $\mathrm{CO}_{2}$ evolution and total soil microbial biomass. Biol. Fert. Soils 1994, 17, 39-44. [CrossRef]

45. Lv, M.; Shao, Y.; Lin, Y.; Liang, C.; Dai, J.; Liu, Y.; Fu, S. Plants modify the effects of earthworms on the soil microbial community and its activity in a subtropical ecosystem. Soil Biol. Biochem. 2016, 103, 446-451. [CrossRef]

46. Lv, M.; Fu, S.L.; Shao, Y.; Lin, Y.; Wu, J.P.; Zhang, W.X. Earthworm Pontoscolex corethrurus stimulated soil CO $\mathrm{CO}_{2}$ emission by enhancing substrate availability rather than changing microbiota community structure. Sci. Total Environ. 2020, 717, 137227. [CrossRef] [PubMed]

47. Shao, Y.; Zhang, W.; Eisenhauer, N.; Liu, T.; Erlian, O.F.; Wang, X.; Xiong, Y.; Liang, C.; Fu, S. Exotic earthworms maintain soil biodiversity by altering bottom-up effects of plants on the composition of soil microbial groups and nematode communities. Biol. Fert. Soils 2019, 55, 213-227. [CrossRef] [PubMed]

48. Zhang, W.; Fu, S. Special issue on the biodiversity and ecological functions of soil fauna. Soil Ecol. Lett. 2021, 3, 83. [CrossRef] 